\title{
Pemberdayaan Anak Panti Asuhan Muhammadiyah Jambi
}

\author{
Intan Lestari ${ }^{1}$, Edwin Permana ${ }^{* 2}$, Indra Lasmana Tarigan ${ }^{3}$, Diah Riski Gusti ${ }^{4}$, Ahmad Sazali ${ }^{5}$, \\ Hamdan Maruli Siregar ${ }^{6}$, M. Ikrar Lagowa ${ }^{7}$, Moh Nabawi ${ }^{8}$, Anisa ${ }^{9}$, Ardian Salsa Rusmana ${ }^{10}$, \\ Betri Yanda ${ }^{11}$ \\ 1, 2, 3, 4, 5, 6, 7, 8, 9, 10, 11 Universitas Jambi, Jambi, Indonesia \\ *edwinpermana86@unja.ac.id
}

\begin{abstract}
Abstrak
Panti Asuhan Muhammadiyah memiliki luas pekarangan yang terbatas, namun masih dapat dimanfaatkan untuk kegiatan budidaya pertanian khususnya budidaya sayuran dan buah-buahan sehingga dapat menghasilkan produk pangan yang bermutu baik dan segar. Kurangnya keterampilan dalam budidaya pertanian pada lahan terbatas, belum adanya keterampilan mengolah produk pangan yang bernilai ekonomis dan manajemen usaha kecil menjadi permasalahan khusus mitra dalam upaya memberdayakan anak-anak panti asuhan. salah satu cara yang dapat dilakukan untuk mengatasi masalah tersebut adalah dengan mengembangkan sistem pertanian vertikultur. Mitra akan ditransfer ilmu dan teknologi tentang budidaya sayuran secara vertikultur dengan menggunakan pupuk organik cair yang dibuat sendiri dari limbah rumah tangga yang bersifat organik dan juga pembuatan pestisida nabati. Selain itu mitra juga akan dilatih untuk mengolah sayuran menjadi produk olahan pangan bernilai ekonomis dan manajemen usaha kecil. Penerapan program ini akan mendatangkan manfaat yang besar bagi kedua mitra dimana secara ekonomi mengurangi pengeluaran untuk membeli kebutuhan akan sayuran segar dan berkualitas, dan apabila hasil melebihi kebutuhan maka dapat dijual sehingga menambah pendapatan mitra. Selain itu program ini akan meningkatkan pengetahuan dan pemahaman anak-anak panti asuhan dalam mengelola usaha kecil secara mandiri dalam rangka meningkatkan taraf hidup dan kesejahteraan penghuni panti asuhan.
\end{abstract}

Kata kunci: Ekonomi; panti asuhan; pertanian; pupuk; vertikultur.

\begin{abstract}
Muhammadiyah Orphanage, the partner of this community service program, has a limited yard area, but it can still be used for agricultural cultivation activities, especially the cultivation of vegetables and fruits so that they can produce good quality and fresh food products. Lack of skills in agricultural cultivation on limited land, lack of skills in processing food products that have economic value and small business management are specific problems of this orphanage to empower its
\end{abstract}


dwellers. The program's proposal to overcome this problem was to develop a vertical farming system. The partner was transferred knowledge and technology about verticulture of vegetables using homemade liquid organic fertilizer from organic household waste and about the production of its pesticides. In addition, partner will also be trained to turn the yielded vegetables into edible food products with economic value and how to manage its small business. The implementation of this program brought great economic benefits to this orphanage since it reduces spending to buy fresh and quality vegetables, and once the yield exceeds the need, the rest can be marketed to increase the partner's income. Finally, this program increases the knowledge and understanding of the orphanage children in managing small businesses independently in order to improve their standard of living and welfare.

Keywords: Agricultural; economy; orphanage, vertilizier; vertikultur.

\section{Pendahuluan}

Panti Asuhan Muhammadiyah Jambi adalah salah satu panti asuhan yang terletak di Kota Jambi. Panti Asuhan Muhammadiyah Aisyiyah Kota Jambi merupakan yayasan panti asuhan yang bergerak dalam bidang sosial, dan keagamaan. Panti ini didirikan tanggal 10 Januari 1984 dan berlokasi di Kecamatan Telanaipura, Kota Jambi. Pendirian panti asuhan berawal dari keprihatinan pengurus Yayasan Muhammadiyah yang melihat anak-anak disekitar lingkungannya banyak anak-anak fakir miskin dan yatim piatu yang sangat membutuhkan kasih sayang, perhatian dan pengayoman untuk kelangsungan masa depan mereka. Saat ini panti asuhan telah membina sejumlah 51 orang anak yang terdiri dari 20 Putera dan 31 Puteri. Ada sejumlah 15 orang berpendidikan SMA, SD dan SMP 30 orang dan sisanya belum bersekolah. Tenaga pengasuh pada panti asuhan ini berjumlah 15 orang.

Panti ini terletak di jantung Kota Jambi yang merupakan kawasan pertokoan dan perkantoran. Lokasi panti asuhan ini cukup strategis yang dapat dimodifikasi untuk menjadi tempat usaha. Anak asuh yang berada di panti asuhan cukup lah banyak dan sudah cukup umur untuk menambah penghasiln mereka sendiri dan dapat mengelola usaha di luar kegiatan pengajaran. Panti Asuhan saat ini belum mempunyai usaha yang produktif dikarenakan keterbatasan keterampilan dam modal yang dimiliki. Keterbatasan pekarangan dan minimnya keterampilan dalam hal produksi dan manajemen usaha menjadi kendala pihak panti dalam upaya meningkatkan taraf hidup bagi para penghuni panti asuhan sehingga kedepan diharapkan mereka memiliki kemandirian dan keterampilan dalam berwirausaha.

Berdasarkan diskusi yang dibangun bersama mitra tersebut, keinginan panti asuhan untuk memanfaatkan pekarangan di sekitar panti yang terbatas untuk kegiatan pertanian khususnya tanaman sayursayuran organik terkendala minimnya keterampilan, baik dari segi produksi/budidaya maupun manajemen usaha. Lebih lanjut mitra menginginkan terbentuknya sebuah usaha yang dapat dikelola secara mandiri untuk dapat membantu memenuhi kebutuhan hidup demi peningkatan taraf hidup dan kesejahteraan penghuni panti asuhan. Hal tersebut diharapkan melalui kegiatan pengolahan pangan hasil pertanian yang bernilai ekonomis. Jika dilihat dari kondisi pekarangan di sekitar gedung panti asuhan yang tidak terlalu besar atau terbatas, sangat memungkinkan untuk dikembangkan model pertanian vertikultur. Kelebihan sistem pertanian vertikultur di antaranya adalah: (1) Efisiensi dalam penggunaan lahan. (2) Penghematan pemakaian pupuk dan pestisida. (3) Dapat dipindahkan dengan mudah karena tanaman diletakkan dalam wadah tertentu.

(4) Mudah dalam hal monitoring/pemeliharaan tanaman. Dalam model ini, jenis tanaman yang dapat ditanam adalah berupa sayuran semusim (sawi, selada, kubis, wortel, tomat, terong, cabai dan lain-lainnya). 
Selain dapat menambah gizi, hasil berlimpah dapat dijual untuk menambah pendapatan panti asuhan. Selain itu lingkungan pun tampak lebih asri dan segar.

Mitra juga tidak perlu mengeluarkan biaya yang besar. Untuk wadah tanaman dapat menggunakan bekas kaleng cat, biskuit atau wadah plastik minyak pelumas. Selain itu mitra dapat pula memanfaatkan botol air minum mineral, ember bekas serta dapat memakai kantung plastik jenis polybag. Selain itu juga akan dibuatkan beberapa desain rak vertikultur. Sedangkan untuk menjawab keinginan pihak panti asuhan terkait usaha yang dapat dikelola secara mandiri, anak-anak panti asuhan dapat diberikan keterampilan teknik mengolah hasil pertanian menjadi produk pangan yang bernilai ekonomis sekaligus diberikan keterampilan manajemen usaha kecil dan teknik-teknik mengembangkannya agar menjadi usaha yang kuat dan terjamin kelangsungan hidupnya.

Berdasarkan hasil wawancara dan pengamatan di lapangan, maka diperoleh beberapa permasalahan mitra yaitu: (1) Pekarangan yang luasnya terbatas yang belum termanfaatkan kegiatan pertanian. (2) Keterbatasan keterampilan dalam memanfaatkan pekarangan yang terbatas/sempit. (3) Tidak memiliki keterampilan dalam pembuatan rak vertikultur, pembuatan pupuk organik cair dan pestisida. (4) Belum memiliki keterampilan teknik mengolah hasil pertanian menjadi produk pangan yang bernilai ekonomis dan bergizi. (5) Belum memiliki keterampilan manajemen usaha kecil serta teknik-teknik mengembangkannya agar menjadi usaha yang kuat dan terjamin kelangsungan hidupnya.

Solusi yang dapat ditawarkan untuk mengatasi permasalahan mitra, seperti: (1) Pelatihan serta pendampingan sistem pertanian vertikultur sebagai solusi keterbatasan lahan, yang dimulai dari cara pembuatan rak vertikultur, teknik budidaya secara vertikultur. (2) Pelatihan serta pendampingan keterampilan pembuatan pupuk organik cair dari limbah rumah tangga, dan (3) Pelatihan serta pendampingan keterampilan dan pembuatan pestisida, (4) Pelatihan serta pendampingan keterampilan diversifikasi produk olahan pangan yang bernilai ekonomis dan bergizi yang siap dipasarkan. (5) Pelatihan dan pendampingan terkait manajemen usaha skala kecil dan teknik-teknik mengembangkannya agar menjadi usaha yang kuat dan terjamin kelangsungan hidupnya.

Luaran dari solusi yang ditawarkan di atas antara lain: (1) Panduan tentang pembuatan rak vertikultur, teknik budidaya secara vertikultur, pembuatan pupuk organik cair dari limbah rumah tangga, dan pembuatan pestisida nabati, pengolahan pangan bernilai ekonomis, dan manajemen usaha kecil dan teknikteknik mengembangkannya agar menjadi usaha yang kuat dan terjamin kelangsungan hidupnya (2) Produk berupa sayuran organic, pupuk organik cair, pestisida nabati, olahan pangan, dan model rak vertikultur (3) Artikel ilmiah yaitu jurnal pengabdian yang memiliki ISSN (4) Artikel pada media massa cetak/ elektronik dan (5) Video Kegiatan.

\section{Metode}

Berdasarkan fakta yang ada dan setelah berdiskusi dengan mitra, maka yang menjadi persoalan prioritas mitra adalah bagaimana upaya mitra untuk memberdayakan anak-anak panti asuhan dengan keterbatasan yang dimilikinya, baik itu lahan dan keterampilan dibidang produksi dan manajemen. Untuk mengatasi permasalahan tersebut, tim dan mitra sepakat untuk mengembangkan pertanian sistem vertikultur dan keterampilan mengolah hasil pertanian serta manajemen usaha kecil. Bentuk partisipasi mitra adalah dengan terlibat aktif dalam seluruh rangkaian kegiatan, menyediakan tempat meletakkan bahan dan alat, menyiapkan lokasi untuk ceramah dan demonstrasi, dan menyiapkan pekarangan untuk budidaya tanaman sayuran dan pengolahan produk pangan. Secara lengkap gambaran pelaksanaan kegiatan pengabdian yang merupakan hasil diskusi dengan kedua mitra seperti terlihat pada tabel berikut ini. 
Tabel 1

Gambaran Pelaksanaan Kegiatan Pengabdian

\begin{tabular}{|c|c|c|c|}
\hline NO & $\begin{array}{c}\text { Jenis dan Diskripsi Kegiatan untuk Memecahkan } \\
\text { Masalah Mitra }\end{array}$ & Pelaksana & Luaran \\
\hline 1. & $\begin{array}{l}\text { Persiapan: } \\
\text { a. Tim kerja berkoordinasi dengan mitra, } \\
\text { pemerintah, dan Unit Pengabdian Masyarakat } \\
\text { Universitas Jambi dalam rangka pelaksanaan } \\
\text { kegiatan. } \\
\text { b. Sosialisasi. Dilakukan pada awal kegiatan untuk } \\
\text { memberikan informasi kegiatan yang akan dilakukan } \\
\text { pada kedua mitra, serta mendiskusikanwaktu } \\
\text { kegiatan, penentuan lokasi, dan bagaimana } \\
\text { pelaksanaan kegiatan. Juga dilakukan persiapan } \\
\text { alat dan bahan. }\end{array}$ & $\begin{array}{l}\text { Tim } \\
\text { pelaksana } \\
\text { PKM dan } \\
\text { Mitra }\end{array}$ & \\
\hline 2. & $\begin{array}{l}\text { Pelaksanaan kegiatan: } \\
\text { 1. Ceramah dan diskusi. Materi disiapkan oleh pemateri } \\
\text { dalam bentuk handout dan leaflet, materi akan } \\
\text { dibagikan satu minggu sebelum kegiatan untuk } \\
\text { dipelajari mitra. Pemateri dari tim pengusul atau nara } \\
\text { sumber yang mempunyai keahlian/kepakaran terkait } \\
\text { materi. Materi-materi yang disampaikan meliputi: } \\
\text { pembuatan rak vertikultur, teknik budidaya vertikultur, } \\
\text { pembuatan pupuk organik cair dari limbah organik } \\
\text { rumah tangga, pembuatan pestisida nabati, pengolahan } \\
\text { pangan bernilai ekonomis, danmanajemen usaha kecil }\end{array}$ & $\begin{array}{l}\text { Tim } \\
\text { pelaksana } \\
\text { PKM dan } \\
\text { Mitra }\end{array}$ & $\begin{array}{l}\text { Panduan tentang: } \\
\text { a. Pembuatan rakvertikultur } \\
\text { b. Budidaya tanaman sayuran } \\
\text { organiksecara vertikultur } \\
\text { c. Pembuatan pupuk organik } \\
\text { cair dari limbah rumah } \\
\text { tangga } \\
\text { d. Pembuatan pestisida } \\
\text { nabati } \\
\text { e. Pembuatan produkolahan } \\
\text { pangan } \\
\text { f. Manajemen usaha } \\
\text { kecil }\end{array}$ \\
\hline & $\begin{array}{l}\text { 2. Demonstrasi. Tim pelaksana menyiapkan alat dan } \\
\text { bahan yang dibutuhkan. Pemateri memperagakan } \\
\text { prosedur membuat produk. Materi yang akan } \\
\text { didemonstrasikan yaitu pembuatan: rak vertikultur, } \\
\text { pembuatan pupuk organik cair dari limbah organik } \\
\text { rumah tangga, pembuatan pestisida nabati, dan } \\
\text { pengolahan pangan bernilai ekonomis }\end{array}$ & & $\begin{array}{l}\text { Produk: } \\
\text { a. Rak vertikultur } \\
\text { b. Pupuk organikcair } \\
\text { c. Pestisida nabati } \\
\text { d. Olahan pangan }\end{array}$ \\
\hline & $\begin{array}{l}\text { 3. Demonstrasi. Tim pelaksana menyiapkan alat dan } \\
\text { bahan yang dibutuhkan. Pemateri memperagakan } \\
\text { prosedur membuat produk. Materi yang akan } \\
\text { didemonstrasikan yaitu pembuatan: rak vertikultur, } \\
\text { pembuatan pupuk organik cair dari limbah organik } \\
\text { rumah tangga, pembuatan pestisida nabati, dan } \\
\text { pengolahan pangan bernilai ekonomis }\end{array}$ & & $\begin{array}{l}\text { Demplot tanaman } \\
\text { sayuran }\end{array}$ \\
\hline
\end{tabular}




\begin{tabular}{|l|l|l|l|}
\hline & $\begin{array}{l}\text { 4. Demplot: Tim pelaksana dan mitra menentukan lokasi } \\
\text { dan pekarangan yang akan dijadikan model, } \\
\text { menentukan jenis sayuran yang akan ditanam, waktu } \\
\text { penanaman, pemupukan, dan pemeliharaan yang akan } \\
\text { dilakukan. Tim menyiapkan alat, bahan, tanaman/bibit, } \\
\text { dan hasil praktik untuk diaplikasikan, serta peserta } \\
\text { menyiapkan pekarangan }\end{array}$ & & \\
\hline & $\begin{array}{l}\text { Pendampingan: Tim menyusun jadwal } \\
\text { pendampingan, dan membuat catatan pada logbook, } \\
\text { serta melakukan diskusi dengan mitra berkaitan } \\
\text { dengan penerapan ipteks. }\end{array}$ & Publikasi & \\
\hline 3 & $\begin{array}{l}\text { Monitoring/Evaluasi : } \\
\text { Monitoring/evalusi dilakukan setiap saat, sejak dimulai } \\
\text { kegiatan hingga selesai. Monitoring dan evaluasi } \\
\text { dilakukan untuk melihat dampak kegiatanterhadap } \\
\text { permasalahan mitra. }\end{array}$ & $\begin{array}{l}\text { Tim } \\
\text { pelaksana } \\
\text { PKM dan } \\
\text { mitra }\end{array}$ & \\
\hline
\end{tabular}

\section{Hasil dan Pembahasan}

Pada kegiatan pengabdian kepada masyarakat yang dilaksanakan pada Panti Asuhan Muhammadiyah ini adalah terlaksananya pemberdayaan anak-anak panti asuhan untuk meningkatkan kemampuan mereka yang kelak dapat berguna di masyarakat. Adapun beberapa kegiatan yang dilaksanakan di panti asuhan Muhammadiyah yaitu Pembuatan Vertikultur, Pembuatan Pupuk Organik Cair, Pembuatan Pestisida dan Pembuatan Olahan Keripik. Sebelumnya pada tahapan awal pengabdian ini sudah dilaksanakan melalui survei untuk mengidentifikasi sasaran secara terperinci meliputi survei tempat serta identifikasi kebutuhan Panti Asuhan Muhammadiyah. Kemudian tahap selanjutnya dilakukan kontrak perjanjian kerjasama antar Pengurus Panti Asuhan setempat dengan pihak pelaksana program pengabdian agar bisa melakukan kegiatan pengabdian di lingkungan tersebut.

Pertemuan dengan pengurus panti membahas tempat, waktu pelaksanaan pelatihan dan melakukan beberapa persiapan kecil. Kegiatan ini cukup memakan jarak waktu yang cukup lama dengan tahapan kegiatan sebelumnya akibat sulitnya menemukan waktu bertemu yang cocok antara tim pelaksana dengan pengurus panti yang cukup sibuk. Sasaran dari kegiatan pengabdian ini adalah anak-anak panti asuhan yang membutuhkan skill dan kemampuan yang dapat membantu anak-anak tersebut nantinya, dan dapat menunjang kemampuan mereka dalam bermasyarakat. Sebelum proses pelatihan dilaksanakan, pihak tim pengbdian mempersiapkan peralatan penunjang dan bahan-bahan yang dibutuhkan untuk membuat beberapa peralatan.

\section{Persiapan Pelaksanaan Kegiatan}

Sebelum proses pelatihan dilaksanakan, pihak tim pengbdian mempersiapkan peralatan penunjang dan bahan-bahan yang dibutuhkan untuk membuat beberapa peralatan. Beberapa langkah dalam tahapan ini adalah: 


\section{a. Pembuatan Vertikultur}

Alat Vertikultur dibuat terlebih dahulu oleh dosen dan beberapa mahasiswa. Langkah awal dalam melakukan budidaya tanaman secara vertikultur adalah menyiapkan kontruksi rak vertikultur. Alat dan bahan yang digunakan, yaitu meteran, bor, dan paralon berukuran 5 inchi beserta penutupnya. Adapun tahap-tahap pembuatannya adalah sebagai barikut:

1. Memotong paralon sepanjang 1-1,5 m

2. Mengukur jarak lubang tanam yang dibuat menyilang dengan ukuran $50 \mathrm{~cm}$.

3. Membuat lubang tanam sesuai dengan jarak lubang tanam yang telah ditentukan menggunakan bormelingkar.

4. Menutup bagian bawah paralon menggunakan penutup paralon.

Setelah konstruksi rak vertikultur selesai dibuat, langkah selanjutnya adalah melakukan proses budidaya tanaman. Berikut adalah beberapa tahap yang dilakukan dalam proses budidaya tanaman secara vertikultur, yaitu:

1. Mengisi media tanam pada rak vertikultur menggunakan campuran tanah, sekam padi, dan pupuk organik dengan perbandingan 1:1:1.

2. Memilih benih tanaman yang akan ditanam menggunakan benih yang bersertifikat. Sebelum digunakan benih terlebih dahulu direndam menggunakan air, kemudian dipilih benih yang bernas (benih yang tenggelam).

3. Penanaman benih dilakukan secara langsung pada rak vertikultur ataupun dengan pemindahan bibithasil persemain benih di tempat yang terpisah. Bibit yang dipindahkan sebaiknya telah memiliki minimal 2 helai daun.

4. Melakukan pemeliharaan tanaman, antara lain:

a. Penyiraman dilakukan dengan cara menyiramkan air pada media tanam sesuai dengan kondisinya. Upayakan media tanam selalu dalam keadaan lembab agar kebutuhan air tercukupi.

b. Pemupukan dilakukan mulai dari penyiapan media tanam untuk pengisian rak vertikultur, kemudian dilanjutkan pada setiap fase pertumbuahan tanaman (vegetatif dan generatif) sebagai pupuk susulan.

c. Pengendalian organisme pengganggu tanaman (hama, penyakit, gulma) dilakukan setelah melakukan pengamatan dan diketahui bahwa populasinya sangat mengganggu pertumbuhan tanaman. Tindakan pengendalian dapat dilakukan dengan penyemprotan pestisida nabati ataupun tidakan pengendalian lainnya yang ramah lingkungan, seperti kultur teknis, fisik dan mekanis.

5. Pemanenan dilakukan apabila kondisi tanaman telah memenuhi secara fisiologis sesuai dengan umur tanam dan jenis tanaman yang dibudidayakan.
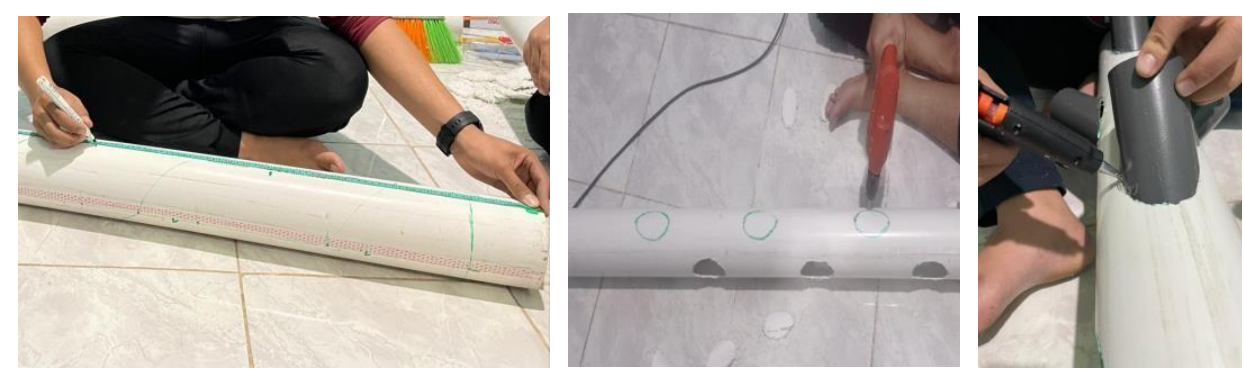

Gambar 1. Persiapan Pembuatan Alat Vertikultur 


\section{b. Pembuatan Pupuk Organik Cair}

Untuk persiapan pembuatan pupuk organik cair ini yang dipilih untuk bahan-bahannya adalah bahan yang mudah didapatkan oleh anak-anak panti asuhan. Adapun alat dan bahan yang dibutuhkan antara lain kulit pisang, botol. ragi, dan air cucian beras. Untuk tahapan-tahapan kegiatan pembuatan pupuk organik cair ini, yaitu:

1. Kulit pisang dipotong kecil-kecil (bisa diganti dengan sayur-sayuran busuk) kemudian masukkanke dalam botol/jerigen.

2. Setelah dimasukkan ke dalam botol, ditambahkan air cucian beras sebanyak $500 \mathrm{~m}$ dan ditambahkan ragi.

3. Terakhir ditambahkan air sampai $3 / 4$ botol dan difermentasi selama 3 hari.

4. Setelah difermentasi, kemudian disaring dan pupuk dapat digunakan.

\section{c. Pembuatan Pestisida}

Bawang putih merupakan salah satu bahan yang sering digunakan dalam pembuatan pestisida nabati karena mudah didapatkan, ekonomis, tidak bersifat fitotoksin, dan efektif dalam mengendalian beberapa jenis hama. Secara umum, berikut adalah cara pembuatan pestisida nabati menggunakan bawang putih (Setiawati, et.al. 2015):

1. Alat dan bahan

Alat dan bahan yang digunakan, yaitu alat penyaring, botol, 85 gr bawang putih, $50 \mathrm{ml}$ minyak sayur, $10 \mathrm{ml}$ detergen, dan $950 \mathrm{ml}$ air.

2. Cara pembuatan

Campurkan bawang putih dan minyak sayur dan diamkan selama 24 jam. Kemudian tambahkan air dan detergen dan aduk hingga merata. Gunakan segera setelah campuran disiapkan atau disimpan dalam botol tidak lebih dari 3 hari.

3. Cara penggunaan

Campurkan larutan pestisida dan air dengan perbandingan $50 \mathrm{ml}$ larutan pestisida dan $950 \mathrm{ml}$ air. Kocok hingga merata dan semprotkan ke seluruh bagian tanaman pada pagi hari.

\section{d. Pembuatan Olahan Keripik}

Pada pembuatan Olahan Keripik ini dibuata dua jenis keripik yaitu keripik bayam dan keripik talas. Adapun cara pembuatannya yaitu:

1. Cara pembuatan keripik Talas

a. Dikupas kulit buah talas

b. Dibersihkan dengan air

c. Diparut buah talas dengan menggunakan parutan

d. Dipanaskan minyak goreng, dan setelah minyak panas, lalu di masukkan parutan buah talas,goreng talas sampai kuning kecoklatan, diagkat dan di tirirskan

2. Pembuatan bumbu keripik

a. 1 siung bawah putih 
b. Disiapkan $1 / 2$ ons bawang merah

c. Dikupas kulit bawang dan dibersihkan

d. Selanjutnya, bawang diblender

e. Digoreng bawang yang telah halus dan ditambah daun seledry

f. Ditambah bumbu penyedap rasa

g. Bumbu yang telah masak diagkat dang ditaburkan pada keripik talas.

3. Pembuatan keripik bayam

a. Dibersihkan daun bayam dengan cara dipisagkan dari tangkainya

b. Lalu dicuci dengan menggunakan air mengalir

c. Pembuatan adonan tepung bayam, yaitu disiapkan tepung tapioca $125 \mathrm{~kg}$ dan tepung beras sebanyak $250 \mathrm{gr}$, lalu dicampurkan kedua tepung dan ditambahkan air sebanyak $250 \mathrm{ml}$ air,

d. Dihaluskan bumbu lainya yaitu bawang merah dan bawang putih sebanyak 15 gr, ketumbar dan kemiri. Lalu dicampurkan ke dalam adonan tepung. Diaduk sampai bumbu tercampur merata,

e. Dimasukkan 1 butir telur kedalam adonan tepung dan diaduk sampai merata, ditambah sedikit bubuk kunyit kedalam adonan dan $1 / 2$ sendok garam. Dan diaduk sampai bumbu tercampur merata.

f. Lalu, Dilanjutkan dengan memasukan helaian daun bayam yang sudah dibersihkan kedalamadonan tepung

g. Lalu dipanaskan minyak goreng,

h. dimasukkan helaian bayam yang sudah dilumuri tepung bumbu kedalam penggorengan yangberisi minyak panas

i. Daun bayam digoreng sampai berwarna coklat dan kering, setelah itu ditiriskan

\section{Pelaksanaan Kegiatan}

Dosen dan mahasiswa Fakultas Sains Dan Teknologi Universitas Jambi, melakukan pengabdian masyarakat dengan mengangkat tema pemberdayaan anak Panti Asuhan Yatim Muhammadiyah Jambi, kegiatan dilakukan pada Sabtu 7 agustus 2021. Dihadiri oleh pengurus panti, dosen dan mahasiswa Fakultas Sains dan Teknologi dan Fakultas Pertanian Universitas Jambi. Kegiatan pengabdian ini diselenggarakan secara luring dengan mematuhi protokol kesehatan COVID-19, yaitu mencuci tangan sebelum memasuki ruangan, memakai masker dan menjaga jarak.

Pelatihan ini, berlangsung di dua titik lokasi yaitu di asrama putri, Sipin, Kota Jambi dan di asrama putra yang bertempat di Pasir Putih. Kegiatan diawali dengan makan siang bersama anak- Anak Panti Asuhan Yatim Muhammadiyah Jambi. Selanjutnya penyampaian kata sambutan dari pengurus Panti Asuhan Yatim Muhammadiyah Jambi, serta dilanjutkan dengan pembukaan acara oleh Ibu Dr. Intan Lestari, M.Si. sebagai ketua tim pengabdian, yang berada di lokasi asrama putri dan pembukaan acara di asrama putra dilakukan oleh Bapak Edwin Permana, S.T., M.T, IPM, ASEAN ENG dengan jumlah peserta yaitu 26 orang putra dan 16 orang putri. 


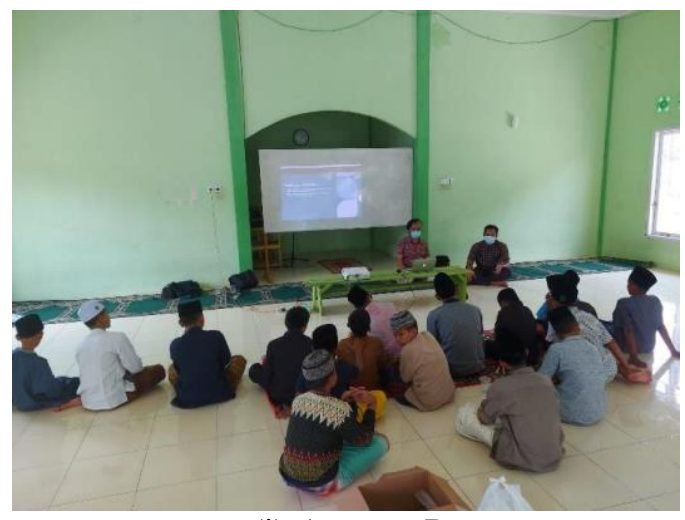

(i) Asrama Putra

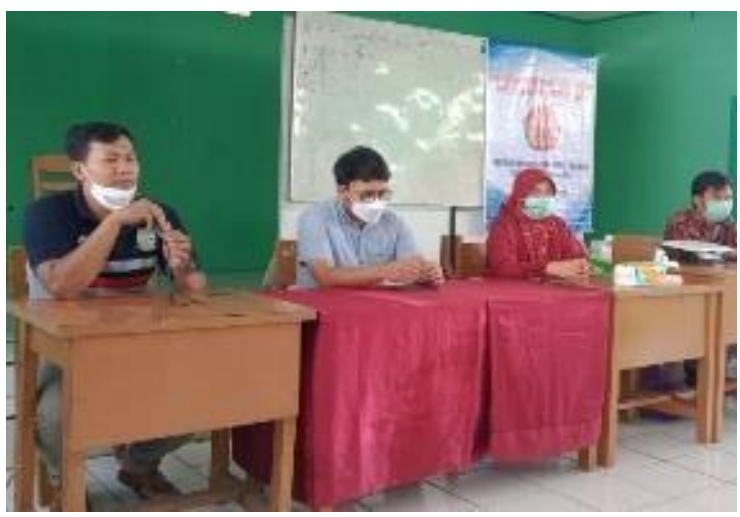

(ii) Asrama Putri

Gambar 2. Pembukaan Pelaksanaan Pengabdian

Kegiatan pelatihan dimulai dengan presentasi oleh tim pengabdian kepada anak-anak panti, mengenai pengetahuan tentang apa itu vertikultur, metodologi budidaya tanaman secara vertikultur, lalu pembuatan pupuk organik cair yang terbuat dari sampah-sampah organik dan cara pengaplikasiannya pada tanaman. Dilanjutkan dengan materi tentang cara pembuatan pestisida yang akan dimanfaatkan sebagai bahan pembasmi hama pada tanamann budidaya yang terbuat dari bahan-bahan yang mudah didapatkan di sekitar lingkungan masyarakat, serta bagaimana pengolahan hasil tanam sampai pada pembuatan dan pengemasan produk. Tujuan dari kegiatan ini adalah memberikan wawasan dan keterampilan kepada anak anak panti, serta harapan ke depanya, dapat meningkatkan kompetensi, kemandirian dan produktivitas anakanak panti di lingkungan masyarakat nantinya.

Adapun rangkaian pelatihan yang telah dilakukan di asrama putra yaitu:

1. Mengenai cara pembuatan vertikultur dan budidaya tanaman secara vertikultur.

2. Pembuatan pupuk organik cair dari bahan kulit pisang, sayur-sayuran yang telah busuk, danpenambahan cucian air beras serta ragi.

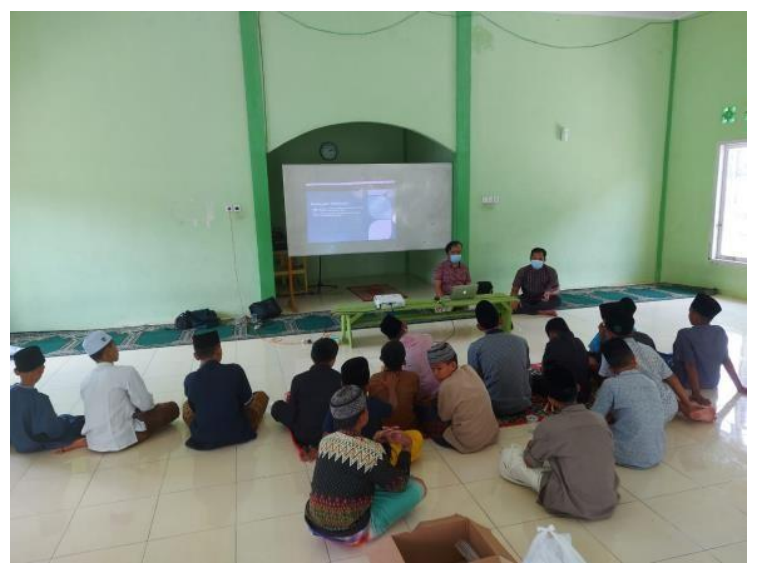

Gambar 3. Pemaparan materi di Asrama Putra

Pelatihan di Asrama Putri yaitu:

1. Cara Pembuatan Pestisida dari bahan bawang putih, minyak sayur, detergen dan air.

2. Cara Pembuatan aneka keripik yaitu keripik dari daun bayam, keripik ubi singkong, ubi talas dan ubi jalar dan pelatihan cara pengemasan produk. 

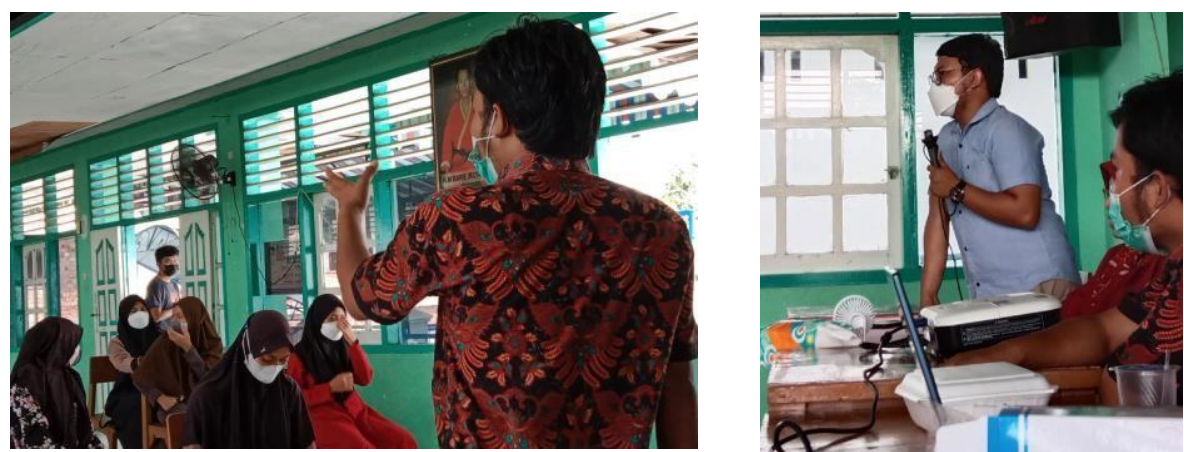

Gambar 4. Pemaparan materi di Asrama Putri

Kegiatan pelatihan ini terbagi menjadi dua tempat yaitu asrama putra dan asrama putri. Kegiatan praktik pembuatan vertikultur dan pembuatan pupuk organik cair dilaksanakan di asrama putra. Sedangkan di asrama putri dilaksanakan pelatihan pembuatan pestisida dan Olahan Keripik. Setelah diperagakan oleh tim pengabdian, anak-anak panti ikut juga mempraktikkan langsung bagaimana cara pembuatan Vertikultur, pembuatan pupuk organik cair, pembuatan pestisida dan olahan keripik yang benar. Anak-anak panti sangat antusias mempraktikkan kegiatan ini pada pembuatan vertikultur. Anak-anak panti diajarkan bagaimana cara mendesain alat vertikultur, membuat lubang pipa dengan cara mengebor, serta cara menanam yang baik. Anak-anak sangat antusias mempraktikkan secara bergantian.
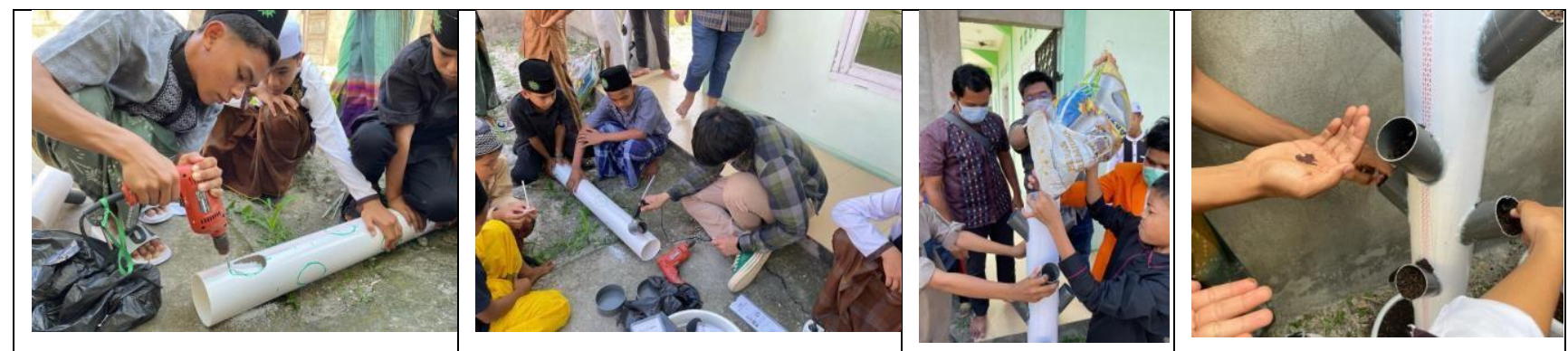

Gambar 5. Praktek Pembuatan Alat Vertikultur

Pada pembuatan pupuk organik cair, anak-anak dibimbing cara-cara pembuatan pupuk organik cair. Kegiatan ini dilakukan dari memotong kulit pisang menjadi ukuran yang lebih kecil, kemudian menakar air cucian beras dan ragi. Berikut rangkaian kegiatan praktek pembuatan pupuk organik cair.
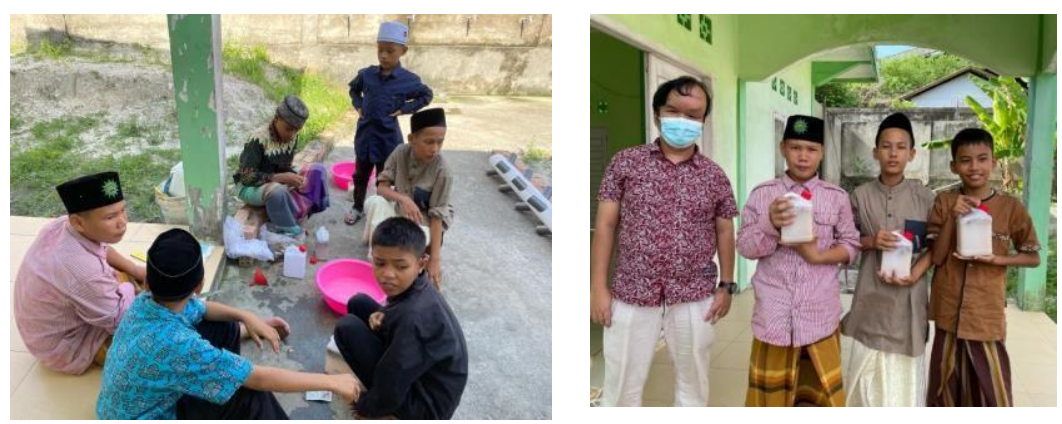

Gambar 6. Praktek Pembuatan Pupuk Organik Cair 
Untuk kegiatan di asrama putri kegiatan yang terlaksana yaitu pembuatan olahan keripik dan pembuatan pestisida. Mahasiswa dan dosen mempraktikkan terlebih dahulu kemudian dilakukan oleh anakanak panti.

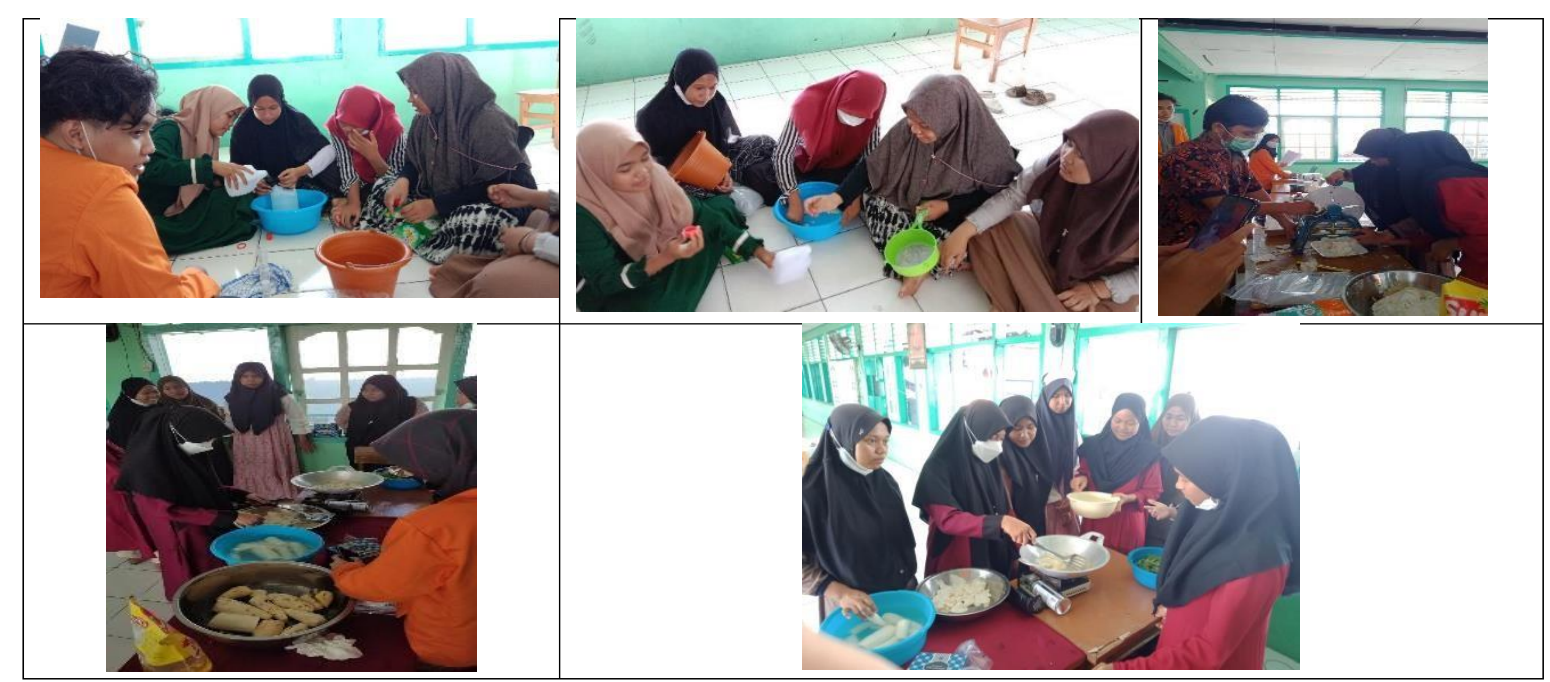

Gambar 7. Praktik Pembuatan Pestisida dan Olahan Keripik

Kegiatan pengabdian ini diharapkan dapat memberikan pengetahuan dan membuka wawasan anakanak panti asuhan untuk lebih produktif, terutama dalam kondisi COVID-19. Pandemi yang mengharuskan untuk stay at home dan stay healthy membuat anak-anak di panti asuhan dapat mengisi kegiatan dengan merawat tanaman dan kegiatan bermanfaat lainya. Kegiatan ini diakhiri dengan doa dan foto bersama, dilanjutkan dengan pemberian seperangkat alat tulis kepada anak-anak panti asuhan berikut bahan-bahan dan alat pembuatan vertikultur. Selain itu dilakukan penyerahan alat pemotong keripik agar dapat dimanfaatkan Panti Asuhan Yatim Muhammadiyah Jambi.
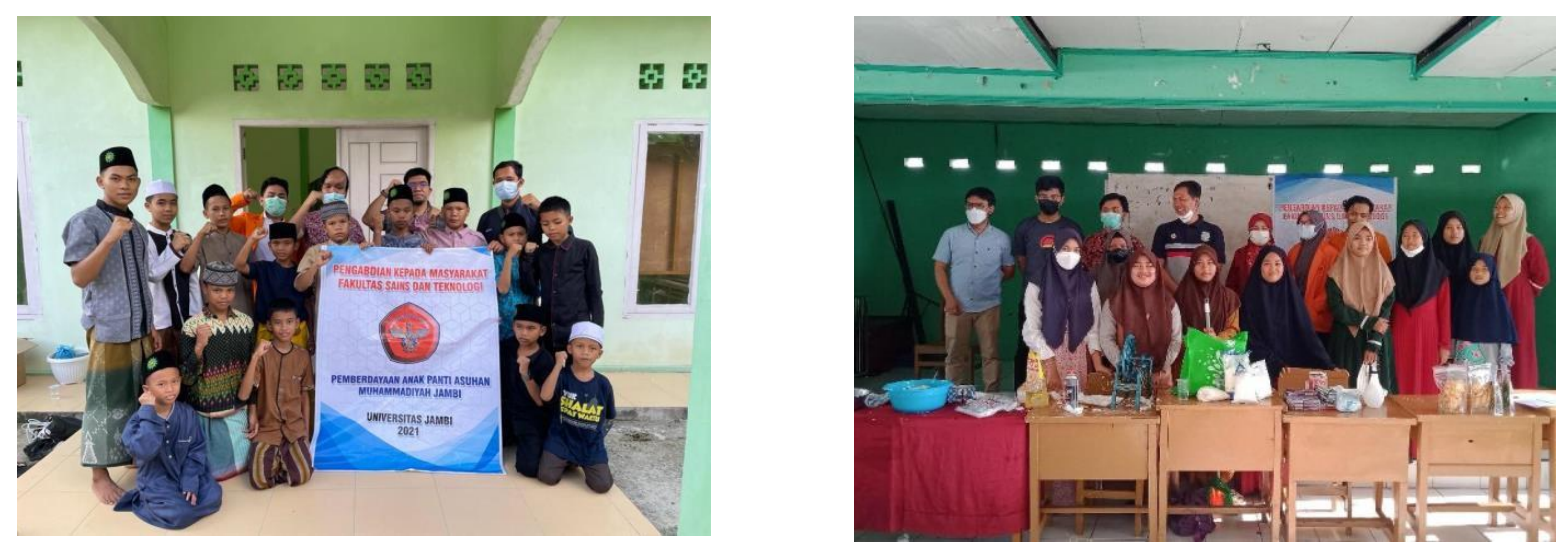

Gambar 8. Foto bersama

\section{Kesimpulan}

Kegiatan pengabdian pemberdayaan anak Panti Asuhan Muhammadiyah kota Jambi ini cukup mendapat apresiasi dan dukungan dari pengurus panti dan anak-anak panti. Diharapkan kegiatan ini dapat 
memberikan pengetahuan lebih tentang manfaat dari pembuatan vertikultur, pembuatan pupuk organik cair, pembuatan pestisida dan olahan keripik lubang sehingga dapat meningkatkan wawasan dan ketrampilan kepada anak anak panti. Harapan ke depanya, dapat meningkatkan kompetensi, kemandirian dan produktivitas anak-anak panti di lingkungan masyarakat nantinya.

\section{Saran}

Disarankan agar anak-anak panti asuhan Kota Jambi yang lain dapat juga mengikuti pelatihan tersebut sehingga dapat mandiri dan berkembang di masyarakat.

\section{Ucapan Terimakasih}

Penulis mengucapkan terima kasih kepada LPPM Universitas Jambi yang telah memberi dukungan moral dan dana terhadap program pengabdian masyarakat ini ini.

\section{Referensi}

Anonimous. (2012). Pengelompokan atau Penggolongan Jenis-Jenis industri dan Ciricirinya. http://wacanapengetahuan.blogspot.co.id/2013/10/pengelompokan-atau-penggolonganjenis_7988.html (29/05/2017).

Dewanti, Ratih, (2013). HACCP Pendekatam Sistematik Pengendalian Keamanan Pangan. Dian Rakyat. Jakarta

Gusti, Diah Riski et al. Pemanfataan Biji Karet Sebagai Bahan Pembuatan Pupuk Organik Cair Di Kud Karya Mukti Kecamatan Jujuhan Ilir Kabupaten Bungo. LOGISTA - Jurnal Ilmiah Pengabdian kepada Masyarakat, [S.1.], v. 5, n. 1, p. 259-265, july 2021. ISSN 2655-951X. Available at:

Permana, E., Ghazali, A., Tarigan, I.L. 2020. Analisis Kandungan Mikroorganisme Lokal (MOL) Dari Biji Karet Terhadap pH, C Organik Dan N Total. Jurnal Teknologi. 13(1), 69-74.

Irianto, Setya, Eny Winaryati dan Siti Aminah. 2015. Ipteks bagi Masyarakat (IbM) Home Industry Nata de Coco (Sari Kelapa). Value Added. Majalah Ekonomi dan Bisnis. Jurnal Ilmiah Program Studi Manajemen Fakultas Ekonomi Universitas Muhammadiyah Semarang. Vol. 11, No. 1 (2015).

Kasmawan, I.G.A. et. al. 2018. Pembuatan Pupuk Organik Cair Menggunakan Teknologi Komposting Sederhana. Vol. 17 No 2.

Jumriari, 2017. Pengaruh Pemberian MOL Terhadap Pertumbuhan dan Produksi Tanaman kangkong darat (Ipomea reptans Poir). Jurnal Pendidikan Teknologi Pertanian, Vol 3 (2017).

Republik Indonesia. 2011. Peraturan Menteri Pertanian nomor 70/Permentan/SR.140/10/2011. Tentang Pupuk Organik, Pupuk Hayati dan Pembenahan Tanah. Kementrian Pertanian

Rumah Zis. 2013. Bangkitkan ekonomi Warga Kelompok Koperasidan

Pengrajin. http://rumahzis.ugm.ac.id/bangkitkan-ekonomi-warga-kelompok-koperasi-danpengrajin-pring- karya-2

Setiawati, W., Murtiningsih, R., Gunaeni, N., \& Rubiati, T. 2015. Peatisida Nabati dari Ekstrak Bawang Putih. Balai Penelitian Tanaman Sayuran. http://balitsa.litbang.pertanian.go.id/ind/index.php/beritaterbaru/421-pestisida-nabati-dari-ekstrak-bawang-putih.html [20 Oktober 2020].

Widnyana I Ketut, I Wayan Wana Pariartha, dan Made Nada. 2014. Ipteks bagi Masyarakat (IbM) Makanan Ringan Khas Bali. Jurnal Bakti Saraswati Vol.03 No.02. September 2014. 